\title{
PANDANGAN DUNIA PENGARANG DALAM NOVEL LA GRANDE BORNE KARYA NH. DINI
}

\author{
Muhammad Yusi Kamhar \\ Magister Pendidikan Bahasa dan Sastra Indonesia \\ Universitas Muhammadiyah Malang \\ yusi.kamhar@yahoo.com
}

\begin{abstract}
Abstrak: Penelitian ini mendeskripsikan pandangan dunia pengarang dalam novel La Grande Borne karya Nh. Dini. Penelitian ini menggunakan pendekatan strukturalisme genetik Lucien Goldmann yaitu pendekatan yang digunakan untuk meneliti tentang struktur pembangun karya sastra, latar belakang kehidupan sosial pengarang, dan pandangan dunia pengarang. Metode yang digunakan dalam penelitian ini adalah kualitatif deskriptif. Sumber data penelitian ini adalah teks novel yang berjudul La Grande Borne karya Nh. Dini. Data penelitian ini adalah berbentuk kutipan-kutipan atau satuan cerita yang terdapat dalam novel La Grande Borne karya Nh. Dini. Teknik pengumpulan data dalam penelitian ini menggunakan teknik tekstual (pustaka). Teknik analisis data yang digunakan adalah teknik analisis deskriptif yang terdiri dari perbandingan antardata dan klasifikasi data. Hasil penelitian menunjukkan pandangan dunia pengarang dalam novel La Grande Borne karya Nh. Dini meliputi (1) pandangan orang Jawa yang berhubungan dengan Tuhan, (2) pandangan orang Jawa yang berhubungan dengan diri sendiri, dan (3) pandangan orang Jawa yang berhubungan dengan sesama.
\end{abstract}

Kata kunci: pandangan dunia pengarang, hubungan dengan diri sendiri

\begin{abstract}
This study describing authors'point of view on a novel written by NH. Dini entitled La Grande Borne. This study applied an approach of structuralism genetic by Lucien Goldmann to observe the structure that builds literature work, author's social background and the point of view of authors 'world. This study applied descriptive qualitative method with data source in form of a novel written by NH. Dini entitled La Grande Borne. Data collection in this study was in the form of quotation or story unit taken from the novel La Grande Borne written by NH. Dini. Data collection technique applied in this study was textual technique (literary technique). Data analysis technique applied in this study was analytical descriptive comprises of data comparison and classification. The result of the study showed the authors 'world point of view in La Grande Borne, a novel written by NH. Dini which includes (1) the point of view of Javanese people related with God, (2) the point of view of Javanese related with inner-self, (3) the point of view of Javanese related with other people.
\end{abstract}

Keyword: authors'world point of view, inner-self relation

\section{PENDAHULUAN}

Sastra ada dalam peradaban manusia semenjak ribuan tahun yang lalu. Kehadiran sastra diterima sebagai realitas sosial, budaya, dan keindahan. Dalam karya sastra, selalu ada perkembangan yang terjadi, baik pada isi atau bentuk karya tersebut. Karena itu, pembaca akan mengetahui realitas sosial budaya dan keindahan sastra sebenarnya yang ditentukan oleh masyarakat penghasil karya sastra tersebut.

Sastra merupakan karya imajinatif dengan menggambarkan kehidupan bermasyarakat yang 
dapat dinikmati, dipahami, dan dimanfaatkan kalangan masyarakat. Hasil imajinasi yang dilakukan pengarang akan dituangkan ke dalam bentuk karya sastra. Bentuk karya sastra tersebut, antara lain, drama, cerpen, puisi, dan novel. Penciptaan karya sastra bukan hanya melalui imajinasi yang dilakukan oleh pengarang, tetapi dapat juga dari pengalaman batin pengarang. Pengalaman batin pengarang berupa peristiwa atau problem dunia yang menarik, sehingga muncul gagasan dan imajinasi yang dituangkan dalam bentuk tulisan.

Sastra yang telah dilahirkan oleh para pengarang diharapkan dapat memberikan kepuasan estetik dan intelektual bagi masyarakat penikmat sastra. Sebaliknya, sering terjadi suatu karya yang tidak dapat dipahami dan dinikmati sepenuhnya oleh sebagian besar masyarakat pembaca. Hal ini dikarenakan karya sastra adalah seni, di mana banyak unsur kemanusiaan yang masuk di dalamnya, khususnya perasaan, ide, semangat, keyakinan dalam suatu bentuk gambaran hidup, yang dapat membangkitkan pesona dengan alat bahasa dan dilukiskan dalam bentuk tulisan, sehingga diperlukan pengetahuan tentang sastra. Berkaitan dengan ini, perlu dilakukan penelitian agar hasil penelitiannya dapat memberikan kemudahan dalam memahami segala aspek yang ada dalam karya sastra itu sendiri, baik makna yang tersuarat maupun yang tersirat bagi masyarakat pembaca. Tugas penelitian sastra tentu tidak hanya terbatas pada penafsiran makna dan lambang dalam teks sastra, tetapi juga harus dapat membantu memudahkan masyarakat pembaca dalam memahami sastra, memberikan penilaian terhadap mutu penciptaan sastra, memberikan sumbangan pemikiran terhadap pertumbuhan dan perkembangan sastra, dan selanjutnya dapat membantu menyediakan bahan-bahan dalam penyusunan teori-teori sastra. Beberapa pengkajian terhadap karya sastra seperti novel dapat dilakukan dengan menggunakan pendekatan sosiologi sastra, penelitian estetika, stilistika, psikologi sastra, kritik sosial, kritik feminis, struktural, semiotik, resepsi, intertekstual, dan strukturalisme genetik.

Satu hal yang tidak mungkin terlepas dari penciptaan karya sastra adalah latar belakang pengarang. Beberapa hal yang melatarbelakangi pengarang dalam melahirkan sebuah karya sastra, antara lain, kondisi kejiwaan si pengarang, faktor religi, pendidikan, ekonomi, sosial budaya atau keluarga. Semua faktor tersebut menjadi dasar terciptanya suatu karya sastra. Dengan demikian, dapat dikatakan bahwa karya sastra merupakan rekaman jiwa si pengarang dengan mediasi bahasa yang akan disampaikan kepada orang lain.

Novel sebagai karya fiksi menawarkan sebuah dunia yang berisi model kehidupan yang diidealkan, dunia imajiner yang dibangun melalui berbagai unsurnya. Semua unsur tersebut sengaja oleh pengarang dibuat mirip, diimitasikan dengan dunia nyata lengkap dengan peristiwa-peristiwa dan latarnya, sehingga sering cerita yang ada dalam novel tersebut dianggap sebagai peristiwa yang benar-benar terjadi dan dialami oleh pengarang itu sendiri. Setelah membaca sebuah cerita novel, mungkin sekali pembaca akan merasakan sesuatu yang belum dirasakan sebelumnya, mungkin merasakan berupa keharuan, ikut merasakan penderitaan, atau merasakan kebahagian seperti yang dialami oleh tokoh Dini dalam novel La Grane Borne ini, sehingga berbagai reaksi emotif yang lain yang dapat menyebabkan pembaca mengalami perubahan dalam menyikapi kehidupan ini.

Dini melalui novel La Grande Borne ini menampilkan tokoh-tokoh yang penuh problematika dalam hubungannya dengan tokoh lain. Hal ini sangat jelas tergambar bahwa masalah-masalah sosial yang terjadi akibat adanya kehidupan tokoh yang dilingkupi ketidaknyamanan, pergolakan hidup tentang cinta, kepercayaan, dendam, persaingan, dan kedudukan dalam keluarga ataupun masyarakat yang terdapat di dalamnya. Problematika tokoh-tokoh tersebut mencerminkan pandangan pengarang dalam menyikapi realitas hubungan sosial yang terjadi. Dengan demikian, pengarang ingin menyuarakan aspirasinya terhadap kenyataan sosial yang 
terjadi. Masing-masing yang dihadapi tokoh dalam hubungan dengan antartokoh maupun lingkungannya dipandang sebagai hubungan yang membentuk totalitas makna.

Keterkaitan pandangan dunia tokoh dengan ruang dan waktu tertentu tersebut, bagi Goldmann merupakan hubungan genetik, karenanya disebut sebagai strukturalisme genetik. Pada bagian lain, Goldmann mengemukakan bahwa pandangan dunia merupakan perspektif yang koheren dan terpadu mengenai hubungan manusia dengan sesamanya dengan alam semesta. Sebagai sebuah analisis strukturalisme genetik didasarkan faktor kesejarahan karena tanpa menghubungkan dengan fakta-fakta kesejarahan pada suatu objek kolektif di mana suatu karya diciptakan, tidak seorang pun akan mampu memahami secara komprehensif pandangan dunia atau hakikat dari yang dipelajari (Goldman dalam Faruk, 2012: $85)$.

Pandangan dunia, bagi Goldmann selalu terbayang dalam karya sastra adalah abstraksi (bukan fakta empiris yang memiliki eksistensi objektif). Abstraksi itu akan mencapai bentuknya yang konkret dalam sastra. Oleh karena pandangan dunia itu merupakan suatu bentuk kesadaran kolektif yang mewakili identitas kolektifnya, maka dia secara sahih dapat mewakili kelas sosialnya. Pandangan inilah yang menetukan struktur suatu karya sastra, sehingga karya sastra dapat dipahami asalnya dan terjadinya (unsur genetik) dari latar belakang sosial tertentu. Keterkaitan pandangan dunia tokoh dengan ruang dan waktu tertentu tersebut bagi Goldmann merupakan hubungan genetik, karenanya disebut strukturalisme genetik. Dalam kaitannya ini, karya sastra harus dipandang dari asalnya dan kejadiannya (Endraswara, 2011: 57).

Selain dua kaidah dasar yang ada pada masyarakat Jawa, orang Jawa juga memiliki pandangan dalam menjaga kelangsungan hidupnya, baik pada tataran yang bersifat vertikal (hubungan manusia dengan Tuhan Sang Maha Pencipta), maupun horizontal (hubungan manusia terhadap diri sendiri maupun masyarakat sekitar).
Adapun sumber-sumber tentang kejawaan seperti berbagai sikap hidup, pandangan hidup serta nilai-nilai Jawa yang hadir dalam setiap kehidupan masyarakat Jawa penulis temukan dalam buku Frans Magnis Suseno: Etika Jawa Sebuah Analisa Falsafa tentang Kebijaksaan Hidup Jawa (1996), Niels Mulder: Kepribadian Jawa dan Pembangunan Nasional (1973), Yana MH: Falsafah dan Pandangan Hidup Orang Jawa (2012).

Berdasarkan beberapa sumber di atas, dapat dijadikan acuan oleh penulis untuk mengetahui cara pandang, sikap hidup serta nilai-nilai masyarakat Jawa dalam menjalani kehidupan. Oleh sebab itu, dijelaskan bahwa orang Jawa memiliki pandangan hidup yang khas, di mana antara dunia, manusia, dan alam semesta adalah satu kesatuan yang saling berkesinambungan. Orang Jawa percaya bahwa ketiga bidang tersebut tidak dapat dipisahkan. Keberadaannya dipandang sebagai kesatuan menyeluruh yang dijadikan pedoman dalam menjalankan kehidupan. Berbeda dengan cara berpikir orang Barat dalam memandang kehidupan dan alam semesta adalah bagian yang berdiri sendiri dan memiliki hukumnya sendiri. Berdasarkan beberapa ulasan tersebut dapat ditarik bahwa kehidupan orang Jawa meliputi (1) pandangan orang Jawa yang berhubungan dengan Tuhan, (2) pandangan orang Jawa yang berhubungan dengan diri sendiri, dan (3) pandangan orang Jawa yang berhubungan dengan sesama.

\section{METODE}

Metode yang digunakan dalam penelitian ini adalah deskriptif kualitatif melalui studi pustaka dengan pendekatan struktruralisme genetik. Data yang diperoleh diolah serta diuraikan dengan menggunakan pola penggambaran deskriptif. Sumber data penelitian adalah novel yang berjudul La Grande Borne karya Nh. Dini yang diterbitkan oleh PT. Gramedia Pustaka Utama Jakarta, cetakan kedua September 2007, dengan tebal 285 halaman. Data dalam penelitiaan ini 
adalah berupa kalimat, paragraf, kutipan-kutipan dialog dan wacana yang diperoleh dari novel yang berjudul La Grande Borne karya Nh. Dini. Teknik yang digunakan adalah dokumentasi dalam novel yang berjudul La Grande Borne karya Nh. Dini.

Teknik analisis data yang digunakan dalam penelitian ini adalah teknik analisis deskriptif yang terdiri dari (1) perbandingan antardata, datadata yang telah diperoleh melalui membaca secara cermat dan teliti dicatat dalam kartu data. Data tentang struktur pembangun, yaitu (a) tokoh, alur dan latar, (b) latar belakang sosial pengarang yang berkaitan latar belakang keluarga, kebiasaankebiasaan, dan lingkungan (c) selanjutnya pandangan dunia yang diwujudkan dengan sikap hidup pengarang dan memiliki hubungan dengan Tuhan, diri sendiri, dan sesama. (2) Klasifikasi data, data-data yang telah dibandingkan kemudian diklasifikasikan berdasarkan jenis data yang sudah ditentukan dalam novel La Grande Borne karya Nh. Dini. Data-data yang telah diklasifikasikan kemudian dimasukkan ke dalam tabel disertai dengan penggunaan angka untuk memperjelas deskripsi yang ada. Sementara itu, kodefikasi atau pengkodean, yaitu data-data yang telah dikumpulkan dan diklasifikasikan kemudian diberi kode atau diberi identitas untuk mempermudah membedakan antardata yang terdapat dalam novel La Grande Borne karya Nh. Dini.

\section{HASIL DAN PEMBAHASAN}

\section{Pandangan Orang Jawa yang Berhubungan dengan Tuhan}

Manusia pada umumnya menganggap segala sesuatu sudah digariskan ketentuannya oleh Sang Maha Pencipta, karena itu setiap manusia pada umumnya dan orang Jawa khususnya berpandangan bahwa manusia harus patuh dan tunduk dalam menjalankan segala perintah yang sudah ditetapkan. Kehidupan adalah suatu keseluruahan yang teratur dan terkoordinasi yang harus diterima dan setiap orang dituntut untuk mampu memposisikan diri terhadap segala sesuatu itu. Konsepsi itu disebut takdir, sesuatu yang sudah ditetapkan Sang Pencipta dan tidak mungkin dapat diubah.

Manusia Jawa percaya garis hidupnya sudah ada yang mengatur (takdir), dan dengan itu mereka menerima (nrima) apa yang menjadi bagiannya dan melaksanakan apa yang menjadi bagiannya itu. Hal inilah yang menjadi dasar orang Jawa melaksanakan apa yang menjadi tugas dan kewajibannya (darma). Darma berarti kewajiban atau tugas hidup. Darma berhubungan dengan anggapan bahwa setiap manusia entah kecil atau besar, banyak atau sedikit mempunyai tugasnya yang khas dalam keseluruhan dan masing-masing berperan dalam penciptaan kerukunan, keselarasan, perdamaian serta kemakmuran masyarakat.

Jika darma tidak dijalankan dengan baik, orang Jawa percaya pada konsep karma sebagai sanksi yang memayungi segala tindak tanduk manusia. Suatu pembalasan setimpal yang diberikan di dunia terhadap perbuatan kurang pantas di masa lalu yang tidak sesuai dengan kewajiban-kewajibanya. Istilah karma lebih menunjuk pada hukum Ilahi terhadap segala tingkah laku di dunia. Pikiran akan karma adalah motif kuat untuk mencegah tindakan-tindakan yang kurang pantas. Namun anggapan tentang karma juga merupakan rangsangan untuk melaksanakan apa yang menjadi darma melalui kewajiban-kewajibannya.

Hal inilah yang melahirkan tiga prinsip dasar orang Jawa dalam menjalankan kehidupan dan menjadi ciri khas yang akan tercermin dalam sikap mereka saat menghadapi dan menanggapi persoalan kehidupan. Sikap hidup yang dimiliki oleh orang Jawa dilakukan sebagai wujud dari pemikiran atau penghayatan terhadap lingkungan (Setiawan, 2015: 5). Sikap hidup orang Jawa diterapkan sebagai hasil dari kombinasi antara pemikiran dan kemantapan hati yang bebas dari kekhawatiran. Berkaitan dengan pandangan atau sikap hidup orang Jawa yang berhubungan dengan Tuhan meliputi sikap eling (ingat), pracaya (percaya), mituhu (taat). Adapun 
pandangan tersebut yang dibawa oleh tokoh Dini dalam menjalani kehidupan rumah tangga di dunia Barat.

\section{Takdir}

Setiap orang mempunyai tempatnya yang spesifik yang sudah ditakdirkan baginya dan daripadanya ia tidak bisa pergi. Tempat itu ditentukan secara jelas melalui kelahiran, kedudukan sosial, dan lingkungan geografis. Hidup dan mati, nasib buruk dan jodoh merupakan nasib (takdir) yang tidak bisa dilawan.

Pandangan itu pula yang ada pada pribadi Dini sebagai istri dan ibu. Ia percaya akan keberadaan takdir dan menerimanya bukan dengan kepasrahan tapi senatiasa sumarah yaitu terus berserah kepada Tuhan YME. Ia tidak begitu saja 'nglokro' putus asa dengan nasib yang telah digariskan Tuhan untuk hidupnya.

Betapapun ketatnya dilindungi atau dikrukubi, kalau memang sudah nasib atau tiba pada garis pepesthen, manusia tidak dapat berbuat sesuatupun untuk mencegahnya. Dalam bahasa Jawa ada senandung yang juga sering diucapkan para dalang wayang kulit yang berbunyi: ana tangis layung-layung, digedhangana, dikuncenana, manungsa mesti mati. Yang penting dalam segala hal kami harus berusaha semaksimal mungkin agar selalu mendapatkan keselamatan. (LGB:11)

Dijelaskan bahwa takdir seseorang sudah ada yang menentukkan, sekuat apapun mereka bersembunyi, betapa pun mereka terlindungi dan terkunci manusia pasti mati. Dalam hal ini manusia tidak dapat menghindari takdir hidupnya. Begitu pula dengan Dini, keberadaannya sebagai manusia yang harus menjalankan skenario dari Sang Pencipta harus dijalani, takdir yang sudah digariskan pada dirinya adalah anugerah bukan malah dijadikan sebagai keadaan yang membuat hidupnya semakin tanpa arah, melainkan menjadi sebuah motivasi hidup yang akan melahirkan ketaatan dalam menjalani perintah Tuhan Yang Maha Kuasa.

\section{Darma}

Manusia mempunyai darma dan tugas kehidupannya ialah untuk melaksanakan darmanya. Setiap orang berkewajiban memenuhi darmanya dengan setia demi kesejahteraan, keselarasan, dan demi mencapai ketentraman batin. Begitu halnya dengan keberadaan tokoh Dini sebagai seorang ibu. Ia harus menjalankan kewajibannya mendidik dan mengayomi (melindungi) kedua buah hatinya (Lintang dan Padang) mengarahkan mereka pada hal yang dianggap baik dalam menjalani hidup. Hal inilah yang dilakukan Dini, yaitu selalu memberi nasihat-nasihat kepada anak-anaknya khususnya Lintang anak gadisnya yang beranjak remaja.

Berhari-hari sebelum berangkat, sedikit demi sedikit aku menyuntikkan beragam arahan kepada anakku. Kuajari dia menghargai hal-hal baru atau pengalaman yang ditemuinya, walaupun itu menyusahkan atau mengesalkan hatinya. Kita harus mampu menerima semua kejadian dari sudut pandang positif, begitu kataku. Jika kita mempunyai landasan pemikiran yang demikian, dalam keadaan apapun, suasana hati bisa dinetralisir. Dan lebih-lebih kutekankan kepada Lintang ialah jangan sampai dia lupa kepada Tuhan. Di saat bergembira, berterima-kasihlah. Di waktu sedih, berdoalah dan mohon kekuatan batin. Kuingatkan anakku betapa doa yang diucapkan dengan ketulusan serta kerendahan hati mengandung kemanjuran magis yang luar biasa. (LGB:121)

Sejenak aku tidak tahu harus menanggapinya dengan kalimat apa. Peranku adalah mendidik anak-anakku menjadi orang yang normal, menjauhi sifat-sifat yang tidak terpuji.

Karena itu kamu jangan meniru ikut munafik. Kalian harus jujur kepada diri 
sendiri dulu, baru kepada lingkungan kalian. Kalau kita bersifat dan bersikap begitu, hati kita tenang, karena kita tidak mempunyai hutang kepada siapa pun,' akhirnya itulah yang kuajarkan kepada anak sulungku. (LGB:235)

Peristiwa yang menimpa Rosa (pengasuhnya anak-anak) membuat Dini semakin sering memberikan nasihat-nasihat pada putrinya. Keadaan Rosa yang hamil di luar nikah, bagi Dini adalah hal yang tidak patut ditiru. Dini menganggap bahwa hubungan seksual hanya diizinkan dalam rangka pernikahan, dan seorang Lintang sebagai seorang remaja putri harus senantiasa berhati-hati dan mawas diri.

Sudah kukatakan bahwa kejadian Rosa berperut besar ketika menikah menjadi perhatian khusus anak sulungku. Ketika dia memulai pembicaraan mengenai hal itu, aku menganggap bahwa inilah kesempatan yang baik untuk mengungkapkan apa yang perlu diketahui seorang perawan sunthi atau remaja putri. ( $L G B: 178)$

Sebagai istri, Dini bukanlah manusia yang begitu saja melepaskan kewajibannya melayani sang kepala keluarga meski keadaan dalam rumah tangganya tengah mengalami disharmonis. Ia tetap menghormati suami pilihannya sendiri, kalaupun kekecewaan itu ada ia berusaha menutupi konflik terbuka apalagi di depan putra-putrinya. Ketika menentukan kelanjutan pendidikan Lintang, Dini membantu sang suami untuk membujuk anak gadisnya agar masuk ke sekolah unggulan Lycee Legion d'honneur.

\section{Karma}

Dalam menjalani hidupnya orang Jawa senantiasa berpikir tentang pembalasan dalam hidup ini. Saat menjalankan darmanya ada tanggung jawab yang nantinya dijadikan sebagai patokan agar tidak melakukan penyimpangan. Semua itu dilakukan semata-mata menghindari ucapan “mengko mundhak kuwalat' (janganjangan kena hukumannya).

Sebagai pribadi, istri dan ibu, Dini mungkin telah melakukan darmanya sekuat dan semampu yang bisa dijalankan. Sebaliknya layaknya manusia yang lain kesalahan ataupun kekhilafan dapat datang tanpa kompromi sebelumnya. Hubungan yang tidak baik dengan suami, membuat Dini melakukan perselingkuhan dengan Bagus atau Maurice. Kekecewaan dengan sang suami yang telah mengurat akar dalam diri Dini membuat ia mencari kesenangan di luar rumah.

Perselingkuhan yang telah dilakukan Dini selama bertahun-tahun akhirnya harus berakhir. Dikabarkan Bagus mengalami kecelakaan dan tidak diketahui keberadaannya. Seperti layaknya kehilangan kekasih saat itu pula Dini hancur, ia mengalami masa sulit meratapi kesalahan, kesepian dan rasa sakit tak berujung bahkan meremehkan kewajibannya tanpa kesadaran sebagai ibu dan istri. Ia mulai tidak peduli dengan sekitar, menganggap hidupnya tidak berarti saat sang belahan jiwa harus pergi. Saat itu dokter juga memvonis Dini dengan beberapa penyakit kronis, mulai dari pneumonia, rematik jantung hingga peradangan dalam rahim. Keadaan yang dialami Dini bisa dikatakan karma akan perbuatannya di masa lalu. Pengkhianatan yang dilakukan Dini adalah kesalahan yang tidak patut untuk dilakukan karena statusnya yang masih menjadi istri orang sekaligus seorang ibu. Oleh sebab itu, kecelakaan yang dialami Bagus dapat dikatakan sebagai hukuman atas tindakannya karena berhubungan dengan istri orang.

Mulai dari saat menerima berita tersebut, detik, menit dan seluruh waktu, kulalui dalam kelesuan. Rutinitas keseharian yang sudah mendarah-daging memang teratur kujalani. Sampai-sampai mengantar anakku yang kedua ke dokter gigi dan menghadiri pertemuan orang tua siswa sekalipun kulaksanakan bukan karena dorongan kesadaran menjalankan kewajiban, melainkan karena aku merasa 
harus melewatkan jam dan hari dengan bergerak, dengan kesibukan. Karena di saat keaktifanku terhenti, langsung kepala dan dadaku direbut oleh berkecamuknya pertanyaan; Di mana kau, Bagus? Bagaimana keadaanmu? Diriku serasa hampa. Aku bergerak dan melakukan segala kegiatan tanpa kesadaran. (LGB:190)

Hari itu juga aku harus masuk klinik di L'hay-les-Roses untuk rontgen. Akhirnya diagnosis diputuskan, ialah paru-paru kiriku hampir penuh air. Selain harus disedot, aku harus beristirahat total dengan cara bersandar selama beberapa bulan. Jadi aku tidak boleh membaringkan diri.

(LGB:223)

Keberadaan karma dalam hal ini adalah sebagai bentuk peringatan atau hukuman di dunia atas perilaku yang kurang tepat. Dini sendiri menyadari penyakit yang diderita sebagai nasib yang harus diterima dari Tuhan karena itu ia tetap menerima tiap kejadian hidupnya dengan sabar dan ikhlas. Hal tersebut tidak membuat seorang Dini begitu lama hancur dalam keterpurukan, kekuatannya menemukan kembali semangat hidup dalam melawan berbagai macam penyakit adalah usaha hidup yang tidak mudah. Ia selalu mendapat cahaya untuk kembali bangkit menghadapi hidup. Kekosongan ditinggal kekasih, bukan berarti ia dapat mengisi dengan kehadiran kekasih baru.

Berdasarkan peristiwa dan konflik yang terjadi dalam dirinya, Dini berusaha mengontrol keseimbangan batin dan untuk menunjukkan diri selalu tenang, halus, terkontrol, rasional dan berkepala dingin. Dini percaya di mana setiap peristiwa memiliki hikmah yang begitu besar untuk dijadikan pegangan serta motivasi untuk melangkah dengan kesadaran. Kesadaran itu bergantung dari Yang Ilahi di mana orang Jawa hidup dengan latar belakang peringatan 'jangan melupakan asalmu'. Hal ini mengisyaratkan di mana seseorang hendaknya ingat 'eling' akan
Allah (Tuhan Yang Maha Pencipta) dan sesuai dengan itu bersikap mawas diri 'waspada'. Karena itulah orang Jawa senantiasa hidup dengan sikap batin yang sudah dijadikan patokan dalam menjalankan kehidupannya.

\section{Sikap Eling (Ingat)}

Sikap eling atau sadar ialah sadar untuk berbakti kepada Tuhan Yang Maha Tunggal atau dalam agama disebut Esa. Dengan demikian, selalu ingat kepada Yang Maha Tunggal maka manusia dapat bersifat hati-hati hingga dapat memisahkan yang benar dan yang salah (yang hak dan yang batil), yang nyata dan yang bukan, yang berubah dan yang tidak berubah. Sikap eling yang dimiliki oleh orang Jawa membuatnya selalu sadar akan sikap dirinya, bahwa semua yang terdapat di dunia ini ada yang menciptakan dan yang mengaturnya. Oleh karena itu, orang Jawa dalam menjalani kehidupannya dituntut agar selalu ingat kepada Tuhan agar bisa membedakan yang baik dan yang buruk (hak dan batil). Begitu juga dengan Dini yang digambarkan melalui tokohnya dalam novel La Grande Borne ini, yang selalu dapat nasihat dari ibunya agar tidak salah dalam menjalani hidup di dunia ini dalam keadaan apapun. Berikut penggalan cerita yang menunjukkan bahwa Dini selalu diberi nasihat oleh ibunya, dan Dini sangat memegang erat nasihat tersebut.

Dalam meraba-raba berusaha untuk tegak kembali, setelah waktu yang lama, amat lama menurut ukuran daya ingetku, pada suatu saat suara ibuku "Eling, ndhuk, eling!" yang di waktu-waktu lampau menjadi tonggak yang selalu kupegang erat, kembali sayup-sayup membelai telinga hatiku. Di waktu itulah sesuatu dorongan membikinku merenung.

Lalu muncul bisikan wahyu yang berupa kesimpulan dari pengalamanku di waktu itu: Tuhan menghendaki agar aku mengenyam aneka ragam kehidupan, tidak selalu sama, mendatar tanpa variasi. Jadi aku wajib 
mengikuti jalan yang digariskan untukku ini dengan kerelaan serta kepasrahan tanpa batas. (LGB:25-26)

Penggalan cerita di atas tergambar bahwa, Dini ketika berada pada posisi yang sangat terpuruk, sehingga membuatnya seperti meluncur tergelincir tanpa kendali dan merasa tidak berdaya untuk bangkit. Pada situasi tersebut Dini terngiang juga dengan kata-kata yang selalu diucapkan ibunya yaitu kata eling. Kata-kata tersebut mengisyaratkan bahwa manusia itu tidak boleh berputus asa karena manusia selain diberi ruh untuk hidup juga diberikan akal yang akan mengajak untuk berpikir apa yang seharusnya diperbuat, ingat bahwa segala sesuatu sudah ada yang mengatur yaitu Tuhan Sang Maha Pencipta. Berikut kutipan yang menyatakan hal tersebut.

Seorang manusia diberi ruh dan akal. Bukan selembar kulit yang dibentuk dan digambari untuk dijadikan salah satu tokoh pewayangan atau dongeng, menunggu agar digerakkan serta dimainkan oleh sang dalang. Dalangku adalah Yang Maha Kuasa, Yang Paling Penyayang, dan Yang Paling Mengetahui jalan cerita hidup yang dijalani. ( $L G B: 26)$

Mengingat (eling) terhadap kodrat sebagai manusia yang dibekali ruh dan akal merupakan salah satu sikap yang harus tertanam dalam diri manusia yang berkaitan dengan hubungan manusia dan Tuhannya. Dengan begitu manusia akan selalu tegar dalam melakoni kehidupan yang sudah ditentukan sejak zaman azali. Begitulah Dini ketika dalam keadaan terpuruk, dia selalu ingat akan nasihat ibunya bahwa semuanya sudah diatur oleh Tuhan Yang Maha kuasa.

Eling, ndhuk, eling!

Pada suatu saat, ketika untuk kesekian kalinya kujeritkan pengaduan kemeranaan dan kegelisahan batinku kepada Yang Maha Kuasa, suara Ibu bagaikan dibisikkan dari kedalaman diriku: "Eling, ndhuk, eling!"
Perlahan-lahan, berangsur-angsur aku bagaikan terbangun, teringat semua kata ibuku yang mengulang-ngulangi bahwa kami ini bukan keturunan orang yang lemah, bahwa kami bukan berasal dari keluarga tanpa sejarah kegigihan yang mendasari pendidikan kami. (LGB:191)

Segala kegelisahan dan keresahan hati yang diraskan Dini, semuanya dia adukan kepada Tuhan Yang Maha Kuasa. di tengah kerapuhannya dia seakan mendapat suntikan energi positif dari nasihat-nasihat ibunya yang selalu mengatakan “eling, ndhuk, eling!" dengan mengingat nasihat tersebut dia perlahan bangkit dan berusaha untuk tegar dalam menyikapi semua masalah yang dia hadapi.

\section{Sikap Pracaya (Percaya)}

Pracaya atau percaya ialah percaya terhadap Sukma Sejati atau utusan-Nya, yang disebut Gusti Sejati. Dengan percaya kepada utusan-Nya berarti percaya kepada jiwa pribadinya sendiri serta kepada Allah. Sikap percaya terhadap utusan yang dikirim.

Jauh di kedalaman batin, aku berdoa semoga keinginan anakku itu diridhoi Tuhan. Karena niat belajar bahasa Inggris adalah satu niat yang baik. Sedangkan aku percaya bahwa Yang Maha Kuasa membantu niatniat yang tidak menyimpang dari kelurusan jalan hidup. (LGB:101)

Selain manusia berkewajiban untuk berusaha, namun hasil tidak wajib untuk didapatkan. Sikap inilah yang terdapat pada pribadi Jawa yang tercermin pada Dini. Ia percaya bahwa segala sesuatu akan bergantung dengan kehendak Tuhan Yang Maha Kuasa. Hal ini terlihat ketika Dini selalu berdoa kepada Tuhan agar semua keinginan dan niat baiknya melihat anaknya belajar bahasa Inggris terkabulkan. Dini juga berdoa semoga niatnya itu tidak menyimpang dengan jalan hidupnya, serta diridhoi Tuhan Yang Maha Kuasa. 
Kalimatku cukup bisa menawarkan ketegangan perasaan anakku. Dia mendekat, lalu memelukku, katanya "Untung ada Maman. Kalau tidak, aku sudah minta kepada Tuhan supaya diberi ayah orang lain saja yang lebih dermawan...."

"Sssst, tidak boleh berkata demikian. Itu berarti kamu menghujat Tuhan! Kita harus selalu bersyukur. Masih beruntung kamu memakai sepatu. Banyak anak-anak di dunia ini yang tidak mempunyai orang tua mampu, tidak bisa membeli kasut kaki yang kedap air, tidak kedinginan jika hujan seperti di hari-hari belakangan ini. Untuk makan saja belum tentu cukup...." (LGB:86)

Lintang begitu kesal dan kecewa terhadap sikap ayahnya yang sangat pelit, dan tidak peduli terhadap kebutuhan anaknya yang semakin banyak karena mengingat anaknya sudah masuk usia remaja. Hal ini yang membuat Lintang mempunyai keinginan untuk berdoa kepada Tuhan Yang Maha Kuasa untuk diberikan ayah orang lain. Dini berusaha menenangkan perasaan anak sulungnya itu, dan meyakinkan bahwa apa yang sudah diberikan Tuhan merupakan nikmat yang sangat besar dan harus disyukuri karena masih banyak orang lain yang hidup di bawah garis kemiskinan. Dini percaya bahwa Tuhan yang lebih mengetahui apa yang dibutuhkan oleh setiap makhluk ciptaan-Nya.

Seperti pada penerbangan-penerbangan jarak jauh di waktu-waktu lampau, nyaris selama dua puluh jam aku hanya bersantai, membaca, mengisi teka-teki silang, merenung sambil menulis atau berzikir. Yang terakhir itulah yang lebih sering kukerjakan. Kumohon pengampunan Gusti Allah, tidak hanya untuk kesalahan atau dosaku sendiri, melainkan juga bagi ayah ibuku, leluhurku, dan semua orang yang kusayangi serta menyayangiku. Dari kesibukan tersebut, tidak hanya ketenangan yang kudapatkan. Dengan berulang kali menyebut nama-Nya, kedamaian batinlah yang menyelubungiku. Aku biasa menyebut nama Tuhan berulang kali untuk berterima kasih atas karunia-Nya, untuk semua hal, dalam semua kejadian yang menguntungkan atau merugikan. (LGB:259)

Sebagai pribadi yang taat dan percaya akan keberadaan Tuhan Yang Maha Kuasa, di sela-sela kesibukan Dini masih menyempatkan untuk merenung dan berzikir kepada Tuhan. Dini percaya bahwa setiap manusia pernah berbuat salah. Karena itu dia berulang kali memohon ampunan kepada Gusti Allah, tidak hanya untuk dirinya sendiri, melainkan untuk semua keluarganya, ibu bapak, dan semua yang dia sayangi. Dia percaya bahwa Tuhanlah yang berhak memberi ampunan, dan semua bentuk kebahagiaan, oleh sebab itu Dini juga berulang kali mengucapkan rasa syukurnya atas segala kenikmatan yang selama ini dibeikan kepadanya.

\section{Pandangan Orang Jawa yang Berhubungan dengan Diri Sendiri}

Manusia menurut kodratnya selain sebagai makhluk sosial adalah sebagai makhluk individu. Sebagai makhluk individu manusia memiliki akal, rasa, dan kehendak sehingga mempunyai tujuan hidup yang berbeda masing-masing individunya. Tujuan hidup yang sama adalah untuk mencapai kebahagiaan bersama. Kebahagiaan hati bersama dapat tercapai apabila masing-masing individu sudah mendapatkan kebahagiaan pribadinya. Kebahagiaan pribadi terlaksana apabila manusia mampu menerpakan sikap rila (rela), nrima (menerima), sabar (sabar).

\section{Sikap Rila (Rela)}

Sikap rila oleh orang Jawa dianggap sebagai sikap menyerah dalam arti positif. Rila terhadap segala sesuatu yang terjadi pada dirinya dan menyerahkan segala keputusan terhadap Tuhan. Rila itu keikhlasan dari hati sewaktu 
menyerahkan segala milikinya, kekuasannya, dan seluruh hasil karyanya dengan tulus dan ikhlas, dengan mengingat bahwa semua itu kekuasaan dan ketentuan Tuhan. Begitu juga Dini, meskipun sepahit apapun yang dia rasakan dalam hati tentang perubahan perilaku ketidaksesuaian suami ketika awal bertemu dengan yang sekarang setelah menikah terhadap keluarga. Namun demikian, Dini selalu berusaha untuk ikhlas menerimanya dan menganggap sebagai sebuah konsekuensi logis dalam menjalani rumah tangganya.

Rasa-rasanya tidak akan habis-habisnya bila aku memikirkan mengapa suamiku begini atau mengapa dia begitu. Tapi aku tidak dapat menahan diriku untuk berbuat demikian, karena di masa itu masih saja aku 'berusaha' memahami mengapa lelaki yang dulu kukenal di Jakarta sedemikian baik dan penuh perhatian terhadapku. (LGB:59)

Pada kutipan di atas menjelaskan bahwa, Dini mengatakan tidak kuasa jika akan mempermasalahkan sikap dan tingkah laku yang selalu membuatnya tidak nyaman. Dini menganggap suaminya yang dulu dengan yang sekarang sangat berubah. Sikap yang dulu perhatian sekarang tidak, namun semua itu Dini menganggap sebagai warna kehidupan yang menjadi sebuah tantangan dalam hidup bersama. Dini selalu berusaha semua yang dihadapinya dengan ikhlas.

\section{Sikap Nrima (Menerima)}

Sikap nrima berarti menerima segala apa yang mendatangi kita, tanpa protes dan pemberontakan. Nrima berarti dalam keadaan kecewa dan sulit seseorang tetap bereaksi secara rasional, tidak ambruk, dan tidak menentang secara percuma. Nrima menuntut kekuatan untuk menerima apa yang tidak dapat dielakkan tanpa membiarkan diri dihancurkan olehnya. Sikap nrima memberi daya tahan untuk menanggung nasib tidak mengenakkan (buruk). Hal ini juga ditunjukkan oleh Dini dalam novel ini bahwa dia selalu menerima apa yang menimpa menjadi sebuah ketentuan Tuhan Yang Maha Pencipta, dan Dini selalu berusaha untuk bangkit dan tegar kembali dalam menjalani kehidupan. Berikut kutipan yang menggambarkan pernyataan tersebut.

Perlahan aku berusaha menegakkan diri kembali. Meskipun tertatih-tatih, tanpa bantuan apa pun atau siapa pun kecuali keyakinannku terhadap Cahaya di Langit serta pelita temaram di batinku, kumulai menata pikiranku dan suasana hatiku guna meneruskan kehidupan.

Lalu seperti di waktu-waktu lampau, sambil menyebut nama Yang Maha Kuasa serta mensyukuri apa pun yang Dia berikan kepadaku, kuteruskan langkahku, setapak di depan lainnya, di kiri dan kanan, kugandeng anak-anakku, Lintang yang remaja dan adiknya Padang. (LGB:27)

Kutipan di atas menunjukkan bahwa Dini telah menerima dengan ikhlas apa yang menjadi ketentuan Tuhan Yang Maha Kuasa atas dirinya dan keluarganya. Dini selalu mencoba untuk bangkit meskipun secara perlahan, dan mensyukuri atas segala sesuatu yang diterimanya. Pada kutipan lain juga terdapat sikap nrima yang dilakukan Dini sebagai berikut.

Aku nyaris tidak peduli. Itu kuserahkan kepada Tuhan Yang Maha Tahu serta Maha Adil. Dengan pemikiran ini, aku lebih tenang menjalani hidupku yang 'terpaksa' masih berlangsung bersama ayahnya anakanakku.

Kepasrahanku tidak berupa kepasifan, tanpa gerak ataupun tanpa usaha. Dimulai usia muda, kami diajari orang tua bahwa kepasrahan adalah sumarah pada kehendak Yang Maha Kuasa, sambil tetap aktif, tetap menjalani tugas masing-masing. Karena setiap makhluk yang diciptakan Tuhan menyandang misi sendiri-sendiri. 
Padahal aku sudah sampai pada titik jenuh dalam menghadapi apa pun yang dilakukan atau dikatakan lelaki pilihanku sendiri itu. Namun aku tidak nglokro. Di dadaku tersimpan Bagus, kekuatan cahaya, pemberi ketegaran, dan penghargaanku terhadap hidup. Kukira, apa pun yang bakal terjadi, sinar itu akan tetap berada di sana, menerangi setiap keputusan dalam langkahku. (LGB:19-20)

Dini sebagai pribadi yang taat dalam beragama selalu menyerahkan segala urusannya kepada Tuhan. Karena Dini berkeyakinan dengan menyerahkan semua permasalahanya kepada Tuhan, hatinya menjadi lebih tenang. Dini juga percaya Tuhan Maha Adil dalam mengatur segala sesuatu untuk hambanya. Oleh sebab itu, meskipun Dini berserah diri kepada Tuhan bukan berarti dia diam tanpa melakukan apaapa. Sebagai wanita Jawa, yang memiliki latar belakang keluarga yang suka bekerja keras dan pantang menyerah masih tetap tercermin dalam dirinya. Hal ini terlihat pada kutipan berikut.

Kepasrahanku tidak berupa kepasifan, tanpa gerak atau pun tanpa usaha. Dimulai usia muda, kami diajari orang tua bahwa kepasrahan adalah sumarah pada kehendak Yang Maha Kuasa, sambil tetap aktif, tetap menjalani tugas masing-masing. Karena setiap makhluk yang diciptakan Tuhan menyandang misi sendiri-sendiri. (LGB:19)

Begitulah sikap dan pandangan Jawa yang tertanam pada diri Dini. Sebagai orang Jawa tidak melepaskan begitu saja cara pandang dan sikap hidupnya meskipun dia hidup di negara Barat. Oleh karena itu, dia tetap memegang erat nilai-nilai tersebut, yakni sikap nrima dan memasrahkan segala sesuatu yang sudah digariskan Tuhan kepadanya. Sikap inilah yang selalu membuat Dini tetap tegar terhadap segala persoalan hidup yang dialaminya.

\section{Sikap Sabar}

Sikap sabar yang dilakukan orang Jawa membuat Dini berhati-hati dalam setiap tindakan yang dilakukan. Sikap sabar membuat orang Jawa tidak tergesa-gesa untuk mendapatkan keberhasilan. Sikap sabar juga menjadikan orang Jawa kuat terhadap ujian hidup. Orang yang bersikap sabar berarti orang yang memiliki kepercayaan terhadap Tuhan dengan keyakinan bahwa semua cobaan dari Tuhan dan orang yang bersikap sabar berarti orang yang memiliki pengetahuan. Hal ini sesuai dengan kutipan di bawah ini.

Setelah bertahun-tahun bersama lelaki itu, masih saja aku mengharapkan dia akan berbuat sesuatu yang 'menyenangkan' kami. Sekurang-kurangnya, melegakan permintaan anak-anakku. (LGB:57)

Dini menyadari bahwa suaminya tidak pernah membahagiakannya, namun di dalam hatinya masih ada setitik harapan suatu saat suaminya akan berubah. Harapan Dini kepada suami, berbuat baik tidak harus kepada dirinya saja, paling tidak berbuat baik kepada anakanaknya Dini sudah ikut merasa merasakan bahagia.

Seandainya aku menuruti kejahialan hatiku, barangkali akan lebih 'mencolok mata suamiku' bila kukatakan bahwa di rekening tabungan, jika dihitung, aku memiliki 'rahasia' sejumlah beberapa tahun uang saku yang dia berikan secara bulanan kepadaku. Tapi aku masih bisa menahan diri. (LGB:83)

Nyaris Dini tidak dapat menahan luapan emosinya dengan sifat suaminya yang sangat pelit, uang bulanan yang diberikan kepada istrinya jauh dari berkecukupan. Dini selalu berusaha untuk menerima mengikhlaskan, sehingga tidak membuat Dini sampai terbakar oleh bara api kemarahanya. Kehadiran anak-anaknya membuat 
Dini lebih berpikir panjang dan tidak tergesa-gesa dalam mengambil sikap. Dia tidak ingin merusak masa depan anak-anaknya dengan sebab hanya ingin menuruti kebutuhan sendiri saja.

Bibirku menggelitik ingin menambahi lagi bermacam 'keanehan sifat' lelaki pilihanku sendiri itu. Tetapi setitik kesadaranku mengingati kehadiran anak-anakku di sana. Kukendalikan diriku, menahan meluncurnya kata-kata kebenaran namun yang akan memperburuk kenangan masa muda Lintang dan Padang.

(LGB:52)

"Mengalah untuk menang", inilah prinsip yang terlihat pada pribadi Dini, karena jika tidak bisa mengendalikan diri karena keanehan sikap suaminya maka akan berdampak buruk terhadap kenangan masa muda anak-anaknya. Oleh karena itu, Dini berpikir panjang terhadap persoalan dalam keluarganya. Selain itu, dia juga percaya bahwa pertengkaran bukanlah langkah untuk menyelesaikan masalah, justru akan menambah masalah karena dapat memperburuk keadaan. Dini berpikir dampak negatif terhadap perkembangan psikologis anak-anaknya. Oleh sebab itu, Dini selalu bersabar terhadap semua itu.

\section{Pandangan Orang Jawa yang Berhubungan dengan Sesama}

Hubungan manusia dengan sesamanya tidak dapat dipisahkan dari hakikat keberadaan manusia di dunia dalam hubungannya dengan Penciptanya. Hubungan manusia dengan sesamanya (hablun minannas) disebut juga hubungan horizontal antara manusia dan manusia. Menjaga hubungan baik antarsesama manusia menjadi sebuah keharusan bagi orang Jawa.

Menurut Mulder (1973: 36) mengatakan untuk mewujudkan kehidupan masyarakat dan keselarasan adalah dengan menjalankan kewajiban-kewajiban sosial. Kewajiban sosial itu menyangkut hubungan sosial, yaitu hubungan dengan sesama dan bagi orang Jawa menjaga hubungan sosial merupakan kewajiban moral yang harus dilaksanakan. Sementara itu, hubungan sosial yang baik itu akan tercipta apabila diwujudkan dalam suasana hormatmenghormati, saling menghargai, dan saling tolong-menolong. Masyarakat Jawa yang sudah memiliki kemantapan moral akan memiliki sikap batin sungkan, wedi, isin, dan ethok-ethok. Sikap batin tersebut dibutuhkan dalam interaksi sosial baik itu dalam ranah keluarga maupun masyarakat.

\section{Sikap Wedi (Takut)}

Sikap wedi bagai orang Jawa biasanya terwujud dalam sikap yang telah terbentuk semenjak anak-anak. Wedi orang Jawa akan muncul saat bertemu atau bersapa dengan orang yang harus dihormati melakukan dan berusaha untuk tidak melakukan suatu tindakan yang dianggap tidak enak. Sementara Suseno (1985: 63) mengatakan wedi berarti takut, baik sebagai reaksi terhadap ancaman fisik maupun sebagai rasa takut terhadap akibat kurang enak suatu tindakan. Sikap wedi terhadap sesuatu yang dianggap gaib serta wedi akan beban moral yang akan ditanggung jika melakukan kesalahan. Dalam hal ini tercermin pada kutipan berikut.

Sssst, tidak boleh berkata demikian. Itu berarti kamu menghujat Tuhan! Kita harus selalu bersyukur. ( $L G B: 86)$

Lintang merasa kesal terhadap sifat ayahnya yang pelit dan tidak peduli terhadap kebutuhan anak-anaknya, sehingga dia mengatakan "Untung ada maman. Kalau tidak, aku akan minta kepada Tuhan supaya diberi ayah orang lain saja yang lebih dermawan," mendengar ucapan Lintang, Dini langsung menasihati anaknya. Dini merasa takut akan 'kualat' akibat doa anaknya yang kurang baik terhadap ayahnya.

Selama anakku laki-laki itu belum mengatakan bahwa dia melihat kakaknya sedang berjalan menuju gedung di mana kami tinggal, hatiku akan merasa belum damai. (LGB:24) 
Dini sangat khawatir dan cemas ketika anaknya keluar rumah seorang diri, dia takut terjadi hal-hal yang tidak dia inginkan pada anaknya, meskipun dia menyibukkan dirinya dengan kesibukan-kesibukan, akan tetapi tetap merasa cemas karena dia merasa memiliki tanggung jawab moral terhadap keselamatan anaknya. Dini meminta anaknya yang kedua (Padang) membuka jendela kamarnya untuk sekali-sekali menengok keluar arah pemberhentian bus yang datang dari arah Stasiun Grigny. Begitu juga ketika anaknya Lintang minta izin akan ke rumah temannya meskipun jarak yang tidak terlalu jauh dari apartemen tempat tinggalnya. Dini akan merasa khawatir dan cemas terhadap keselamatannya. Hal ini sesuai dengan kutipan berikut.

Jika Lintang minta izin akan ke rumah temannya yang tinggal tidak jauh dari gedung kami, panjang lebar aku berpesan agar dia berhati-hati, jangan bebicara kepada orang asing, bahkan bila orang itu menanyakan alamat tetangga sekalipun!

\section{(LGB:116)}

Begitulah sikap wedi yang diperlihatkan Dini ketika Lintang meminta izin akan ke rumah temannya. Dini selalu berpesan agar selalu berhati-hati dan tidak berbicara denga orang yang tidak dikenalnya. Selain itu, apabila ada orang yang meminta alamat tetangga sekali pun jika orang itu tidak dikenalnya Dini tidak boleh dilayani, begitulah pesan Dini kepada anaknya. Hal ini dilakukan Dini tidak lain karena perasaan taku, dan tidak ingin terjadi apa-apa terhadap anaknya Lintang. Sikap wedi yang muncul pada diri Dini tidak hanya kepada keselamatan anak-anaknya saja, akan tetapi kepada binatang sekalipun ini terlihat pada kutipan berikut.

“Awas Miu! Hati-hati!” aku tidak bisa menahan seruan kecilku.

Aku khawatir kucing itu akan menerkam teman kami. Karena melihat perbedaan ukuran tubuh keduanya, aku yakin dengan sekali di gigit saja, Miu pasti akan luka atau bahkan mati.

Dengan jantung yang berdetak keras, kuawasi kedua binatang itu saling menyentuhkan hidung. Aku memanggil, "Miu! Ayo masuk! Miu!" (LGB:64-65)

Dini begitu khawatir terhadap keselamatan kucing kesayangannya ketika keluar bermain bersama kucing lain. Hatinya tidak tenang karena melihat ukuran tubuh kucingnya lebih kecil, sehingga dia merasa takut teman kesayangannya itu akan diterkam. Diam-diam Dini mengawasi binatang kesayangannya itu dikarenakan rasa takut terjadi apa-apa dengannya.

\section{Sikap Ethok-ethok (Pura-pura)}

Sikap ethok-ethok bagi orang Jawa dianggap sebagai sikap yang positif karena tidak menunjukkan apa yang sebenarnya terjadi pada diri kita, terutama yang berhubungan dengan sesuatu yang tidak diperkenankan untuk diketahui orang lain. Menurut Greetz (Suseno, 1985: 43) usaha ethok-ethok ini adalah untuk menjaga tingkat keakraban tetap sedang-sedang saja dalam hubungan antar orang, suatu kehangatan ethok-ethok, di mana semua perasaan yang sebenarnya dapat disembunyikan dengan efektif di belakangnya.

Di depan anak-anakku, aku tidak ingin 'mengumumkan' bahwa ada seorang kapten yang lebih mempedulikan kesejahteraanku dalam hal materi dari pada ayah mereka. Bagaimanapun juga, lelaki itu adalah ayah mereka. Jangan sampai aku menghasut atau melenyapkan rasa hormat mereka. (LGB:83)

Meskipun Dini memiliki seorang kekasih yang selalu perhatian dan peduli kepadanya, namun semua itu tidak membuatnya lupa diri dan dengan mudah menggumbar kepada setiap orang termasuk anak-anaknya. Dia bersikap seakan tidak ada apa-apa. Sikap inilah yang disebut ethok-ethok (pura-pura) dalam bahasa Jawa. Dini 
sebagai orang Jawa bersikap ethok-ethok ketika dia digoda oleh Pascal yang selalu menggodanya, Dini berpura-pura dengan tujuan antuk menepis hal-hal dia tidak inginkan terjadi. Hal ini sesuai dengan kutipan berikut.

Kuajak dia ke meja makan supaya duduk berhadeapan dengan jarak tidak terlalu dekat. Di situ langsung kujelaskan bahwa aku tidak tertarik kepadanya, bahwa hubunganku dengan suamiku sangat baik. $(L G B: 242)$

Sikap ethok-ethok (pura-pura) diperlihatkan oleh Dini ketika dia menjelaskan bahwa dia tidak tertarik kepada laki-laki itu dan hubungannya sangat baik dengan suaminya. Namun sebaliknya di dalam hatinya dia tidak membenarkan ucapannya kalau hubungannya baik-baik saja dengan suaminya. Hal ini sebenarnya dilakukan untuk menghindar dari bujuk rayu Pascal (laki-laki yang selalu menggodanya). Sikap ini dipandang baik untuk menjaga perasaan-perasaan negatif yang akan timbul terhadap orang lain jika itu akan merugikan ataupun membahayakan diri sendiri dan orang lain. Hal ini sesuai dengan kutipan di bawah ini.

"Akan kutelepon ke sana sebentar lagi." "Tidak, tidak perlu," dengan 'berani' aku menolak tawaran yang dermawan itu.

"Betul? Kau baik-baik saja? Tu sais que nous t'aimons beaucoup et cette nouvelle doit te secouer terriblement...."

Sekali lagi kuucapkan kata atau kalimat apa saja sebagai basa-basi terima kasih atas perhatian kawanku, lalu komunikasi kuakhiri. (LGB:189)

Sikap ethok-ethok atau berpura-pura terlihat pada kutipan di atas. Jean temannya Dini yang berniat akan telepon kembali, untuk menyelesaiakan pembicaraan akan tetapi Dini menolak dengan alasan "tidak, tidak perlu," penolakan yang Dini lakukan hanyalah sikap basa-basi atau kepura-puraan saja. Sebaliknya,
Dini berpura-pura karena dia merasa merugikan orang lain jika dia berlama-lama, karena dari luar kabin telepon umum sudah membiarkan orang lain mengantre cukup lama.

Selain itu, Dini juga merasa sudah tidak kuasa menahan kesedihannya karena baru saja dia menerima kabar bahwa Bagus (kekasihnya) mendapat kecelakaan dan belum diketahui keberadaannya. Itulah yang membuat dia ingin segera pulang untuk melampiaskan kesedihannya dengan menangis sendirian di rumah, tanpa ada yang mengetahuinya. Kabar tersebut membuat Dini sangat terpukul, dan membuatnya tidak bersemangat untuk beraktivitas, dia terus tenggelam dalam kesedihannya. Sebagai orang Jawa yang sudah tertanam dalam dirinya sikap ethok-ethok selalu diperlihatkan Dini dalam keluarganya, itu bertujuan untuk menyembunyikan keadaan yang sebenarnya. Hal ini sesuai dengan kutipan berikut.

Kalian mau cuci tangan ketika sampai di rumah atau tidak, membenahi pakaian kotor kalian atau tidak, terserah! Aku capek dan sudah bosan. Yang penting aku menyiapkan makanan, membersihkan rumah. Meskipun begitu, asal jangan kalian lupa bahwa aku tetap menyayangi kalian berdua.

\section{$(L G B: 191)$}

Kutipan di atas terlihat Dini sangat tidak peduli terhadap anak-anaknya, ia mengatakan "terserah kalian mau cuci tangan ketika samapai di rumah atau tidak, membenahi pakaian kotor kalian atau tidak terserah aku capek dan sudah bosan". Namun sebenarnya bukan itu alasan Dini tidak mau mengurus anak-anaknya. Dini hanya bersikap ethok-ethok (berpura-pura) untuk menutupi kalau dia sedang diliputi kesedihan yang mendalam, dan Dini sebenarnya sangat sayang kepada anak-anaknya.

Berdasarkan realitas sosial dan peristiwa-peristiwa yang terjadi pada diri Dini menggambarkan bahwa dimensi sosial yang menjadi ciri khas manusia Jawa terdapat 
pada diri Dini. Negeri Barat tidak begitu saja memengaruhi pandangan dan sikap hidup Dini meskipun berada di lingkungan yang memiliki prinsip dan pandangan yang berbeda. Dengan demikian dapat dikatakan bahwa, pandangan hidup merupakan suatu hasil dari cara berpikir dan cara interpretasi tentang pengalaman sosial dalam kultur; pada gilirannya pandangan hidup itu merupakan suatu pedoman bagi pelaksanaan dan perbuatan dalam menjalani kehidupan yang berhubungan antarsesama sehari-hari.

\section{KESIMPULAN}

Pandangan dunia pengarang diwarnai oleh konsep hidup pengarang dalam menjalani kehidupan kaitannya dengan hubungan manusia dengan Tuhan yang ditandai dengan sikap takdir, darma, karma, eling, dan pracaya, kemudian hubungan manusia dengan diri sendiri yang ditandai dengan sikap rila, nrima, sabar dan yang terakhir hubungan manusia dengan sesama manusia yang terwujud dalam sikap wedi dan ethok-ethok. Keseluruhannya dijadikan sebagai cara pandang pengarang dalam menjalani kehidupan dengan penuh kesabaran dan keikhlasan bagaikan filosofi air mengalir.

\section{DAFTAR PUSTAKA}

Endraswara, S. (2011). Metodologi Penelitian Sastra: Epistemologi, Model, Teori, dan Aplikasi. Yogyakarta: CAPS.

Faruk. (2012). Pengantar Sosiologi Sastra: dari Strukturalisme Genetik Sampai PostModernisme. Yogyakarta: Pustaka Pelajar. Mulder, N. (1973). Kepribadian Jawa dan Pembangunan Nasional. Yogyakarta: Gadjah Mada University Press.

Setiawan, A. (2015). Sikap Hidup Wanita Jawa dalam Novel Bekisar Merah dan Novel Midah Si Manis Bergigi Emas. Jurnal Keilmuan Bahasa, Sastra, dan Pengajarannya, 1(1), 1-15.

Suseno, F. M. (1985). Masalah-Masalah Pokok

Filsafat Moral. Yogyakarta: Penerbit Kanisius. 